\title{
Yield and technological quality of sugarcane under irrigation depths and nitrogen fertilization
}

\author{
Marcos F. de Mendoça ${ }^{1}$, José Dantas Neto ${ }^{2}$, Patrícia F. da Silva ${ }^{3}$ \& Emídio C. A. de Oliveira ${ }^{4}$ \\ ${ }^{1}$ Usina Central Olho D’Água S/A, Camutanga, PE, Brasil. E-mail: mendoncamf@gmail.com - ORCID: 0000-0001-6649-5542 \\ ${ }^{2}$ Universidade Federal de Campina Grande/Centro de Tecnologia e Recursos Naturais/Unidade Acadêmica de Engenharia Agrícola, Campina Grande, \\ PB, Brasil. E-mail: zedantas1955@gmail.com - ORCID: 0000-0003-0798-6717 \\ ${ }^{3}$ Universidade Federal de Campina Grande/Centro de Tecnologia e Recursos Naturais/Programa de Pós-Graduação em Engenharia e Gestão dos Recursos \\ Naturais, Campina Grande, PB, Brasil. E-mail: patrycyafs@yahoo.com.br (Corresponding author) - ORCID: 0000-0002-4580-2336 \\ ${ }^{4}$ Universidade Federal Rural de Pernambuco/Departamento de Agronomia, Recife, PE, Brasil. E-mail: emidio.oliveira@ufrpe.br - ORCID: 0000-0002- \\ 9283-7910
}

\begin{abstract}
The objective of this study was to evaluate the stalk yield, sugar yield and technological quality of two varieties of sugarcane under different irrigation depths and nitrogen doses. The experiment was conducted in two consecutive years (2015 and 2016) at Olho D’Água Farm, in Itambé, Pernambuco, Brazil. The experimental design was randomized blocks in the split-split-strip-plot scheme, with four replicates. Treatments consisted of four irrigation depths $(\mathrm{L} 1=12, \mathrm{~L} 2=45, \mathrm{~L} 3=100$ and $\mathrm{L} 4=125 \%$ of the crop evapotranspiration - ETc, plant cane) and (L1 = 10, L2 $=40, \mathrm{~L} 3=100$ and $\mathrm{L} 4=125 \%$ ETc, ratoon cane), four doses of nitrogen $\left(\mathrm{N} 1=0, \mathrm{~N} 2=50, \mathrm{~N} 3=100\right.$ and N4 $=200 \mathrm{~kg} \mathrm{ha}^{-1}$ of $\left.\mathrm{N}\right)$ and two varieties of sugarcane (RB92579 and RB002754). Sugarcane plants irrigated with the highest depths of 1,324.06 and 1,242.3 mm in the plant cane and ratoon cane cycles respectively produced 38.40 and $49.14 \mathrm{t}$ of stalks ha-1 and 0.48 and $1.82 \mathrm{t}$ of sugar ha ${ }^{-1}$ more, compared to those irrigated with the lowest depths of 124.06 and $99.4 \mathrm{~mm}$. The highest stalk yield was obtained with the combination of $120.7 \mathrm{~kg} \mathrm{ha}^{-1}$ of $\mathrm{N}$ and $1266.6 \mathrm{~mm}$ of irrigation depth. Sugarcane technological quality is positively correlated with the increase of the irrigation depth in the plant cane and ratoon cane cycles and negatively correlated with nitrogen.
\end{abstract}

Key words: crop evapotranspiration, effective precipitation, ammonium nitrate, sucrose

\section{Produtividade e qualidade tecnológica da cana-de-açúcar sob lâminas de irrigação e adubação nitrogenada}

\begin{abstract}
RESUMO: Objetivou-se com este estudo avaliar a produtividade do colmo, do açúcar e a qualidade tecnológica de duas variedades de cana-de-açúcar sob diferentes lâminas de irrigação e doses de nitrogênio. O experimento foi conduzido em dois anos consecutivos (2015 e 2016) na Fazenda Olho D’Água, em Itambé, Pernambuco. O delineamento experimental foi em blocos casualizados no esquema de faixas subsubdivididas, com quatro repetições. Os tratamentos foram constituídos de quatro lâminas de irrigação $(\mathrm{L} 1=12, \mathrm{~L} 2=45, \mathrm{~L} 3=100$ e L4 $=125 \%$ da evapotranspiração da cultura - ETc, cana planta) e $(\mathrm{L} 1=10$, L2 = 40, L3 = 100 e L4 = 125\% de ETc, cana soca), quatro doses de nitrogênio $\left(\mathrm{N} 1=0, \mathrm{~N} 2=50, \mathrm{~N} 3=100\right.$ e N4 $=200 \mathrm{~kg} \mathrm{ha}^{-1}$ de N) e duas variedades de cana-de-açúcar (RB92579 e RB002754). A cana-de-açúcar irrigada com as maiores lâminas de $1.324,06$ e 1.242,3 mm na cana planta e na cana soca produziu, respectivamente, 38,40 e 49,14 t de colmo ha-1 e 0,48 e 1,82 t de açúcar ha ${ }^{-1}$ a mais em comparação à irrigada com as menores lâminas de 124,06 e 99,4 mm. A maior produtividade de colmo foi obtida na combinação de $120,7 \mathrm{~kg} \mathrm{ha}^{-1}$ de $\mathrm{N}$ e 1266,6 mm de lâmina de irrigação. A qualidade tecnológica da cana-de-açúcar possui relação positiva com o aumento da lâmina de irrigação na cana planta e na cana soca e, tem relação negativa com o nitrogênio.
\end{abstract}

Palavras-chave: evapotranspiração da cultura, precipitação efetiva, nitrato de amônia, sacarose 


\section{INTRODUCTION}

One of the limitations to the expansion of the sugar-alcohol sector in Brazil and in the world is the fact that sugarcane fields are planted in acidic, low-fertility soils and in regions with lower or even irregular rainfall, which does not meet the water needs of the crop, hence influencing its yield and technological quality (Oliveira et al., 2011; Silva et al., 2014).

Knowledge on the water needs of the crop, associated with the rational management of irrigation and fertilization, in this scenario, are important tools to reduce the effects of water scarcity and, consequently, increase the stalk production potential and technological quality, that is, it aims to meet the water demand of the crop and improve agro-industrial yields (Uribe et al., 2016).

Dellabiglia et al. (2018) state that, for sugarcane, increments in agro-industrial yield require an adequate water and nutritional supply, in particular with the mineral element nitrogen $(\mathrm{N})$, a nutrient with direct effect on sprouting and tillering, influencing the production capacity of the crop in terms of stalk and sugar.

Irrigation, along with fertilization, contributes to high levels of total soluble solids ( ${ }^{\circ}$ Brix), Pol, purity, TRS and sugar yield, providing a better economic yield, since these are limiting factors to sugarcane production because, as their availability increases, the crop expresses its production potential with different responses between varieties (Vieira et al., 2014).

Thus, the objective of this study was to evaluate the stalk and sugar yields and the technological quality of two varieties of sugarcane under different irrigation depths and $\mathrm{N}$ doses.

\section{Material ANd Methods}

Two experiments were conducted in the cycles of plant cane - PC (2015/2016 season) and ratoon cane - RC (2016/2017 season), under field conditions at Olho D'Água II Farm (7 $23^{\prime} 12^{\prime \prime} \mathrm{S}, 35^{\circ} 14^{\prime} 51^{\prime \prime} \mathrm{W}$ and altitude of $119.0 \mathrm{~m}$ ), in the municipality of Itambé, PE, Brazil. According to Köppen's classification, the climate of the region is As, hot and humid with autumn and winter rains and six dry months. The mean air temperature and the total and effective precipitation were obtained from the automatic station installed in the experimental area.

The soil of the experimental area is classified as Albaquult, of medium-clayey texture. The physical and chemical characteristics of the soil in the experimental area are: $\mathrm{Ca}^{2+}, \mathrm{Na}^{+}$, $\mathrm{K}^{+}$, and $\mathrm{Al}^{3+}+\mathrm{H}^{+}=2.6,1.6,0.3$ and $1.7 \mathrm{cmol} \mathrm{kg}^{-1} ; \mathrm{pH}$ (water $1: 2.5)=5.4 ; \mathrm{ECse}=0.4 \mathrm{dS} \mathrm{m}^{-1} ;$ organic matter $=2.1 \mathrm{~g} \mathrm{~kg}^{-1}$; sand, silt and clay $=572,264$ and $164 \mathrm{~g} \mathrm{dm}^{-3}$; bulk density $=1.58$ $\mathrm{kg} \mathrm{dm}^{-3}$; moisture contents at 33.42 and $1,519.5 \mathrm{kPa}=20.6$ and 13.2 $\mathrm{MPa}$, respectively, at $0-20 \mathrm{~cm}$ depth, obtained according to the methodology proposed by Donagema et al. (2011).

Soil tillage consisted of heavy harrowing to incorporate soil correctives and destruction of crop residues, followed by subsoiling and opening of planting furrows. Limestone and agricultural gypsum were used to correct the soil in the amounts of 650 and $1000 \mathrm{~kg} \mathrm{ha}^{-1}$, respectively. Basal fertilization in both cycles was performed using $126 \mathrm{~kg} \mathrm{ha}^{-1}$ of $\mathrm{P}_{2} \mathrm{O}_{5}$ and 1.0, 1.0, $0.5,0.3$ and $0.2 \mathrm{~kg} \mathrm{ha}^{-1}$ of $\mathrm{Zn}, \mathrm{Mn}, \mathrm{Cu}, \mathrm{B}$ and Mo, respectively, applied in the form of liquid chelated fertilizers.
Planting was carried out on January 5, 2015, in furrows spaced by $1.5 \mathrm{~m}$ between rows. Stalks were distributed in the furrow in the end-to-end system with 3 buds per sett, in order to reach 18 buds per linear meter, with a total planting area of 10,304.0 $\mathrm{m}^{2}$. Weed control was performed using herbicide.

Treatments consisted of four irrigation depths (in plant cane - PC: $\mathrm{L} 1=12 ; \mathrm{L} 2=45 ; \mathrm{L} 3=100$ and $\mathrm{L} 4=125 \%$ of replacement of crop evapotranspiration - ETc, corresponding to $124.06 ; 473.67 ; 1,061.47$ and $1,324.06 \mathrm{~mm}$, respectively, and in ratoon cane - $\mathrm{RC}$ : $\mathrm{L} 1=10 ; \mathrm{L} 2=40 ; \mathrm{L} 3=100$ and $\mathrm{L} 4=125 \%$ of ETc, corresponding to $99.4 ; 397.5 ; 993.9$ and $1242.3 \mathrm{~mm}$ ), four doses of nitrogen $(\mathrm{N} 1=0 ; \mathrm{N} 2=50 ; \mathrm{N} 3=100$ and N4 = $200 \mathrm{~kg} \mathrm{ha}^{-1}$ of $\mathrm{N}$ ) based on the nutritional requirements of the crop, with ammonium nitrate as $\mathrm{N}$ source, and two varieties of sugarcane (RB92579 and RB002754). The experimental design was randomized blocks in a split-split-strip-plot scheme, with four replicates, in which the main plot corresponded to the irrigation depth (strip), with nitrogen doses in the subplots and the varieties in the sub-subplots.

The variety RB92579 is a plant whose relevant characteristics are high sprouting, high tillering, high yield, high sucrose content and medium fiber content, besides being highly responsive to irrigation (Simões Neto et al., 2013). The variety RB002754 has good sprouting, medium tillering, tall size, in addition to high yield, high sucrose content and medium fiber content (Oliveira et al., 2014).

The irrigation depths were arranged in strips containing five cultivation rows, with width of $7 \mathrm{~m}$ and length of $92 \mathrm{~m}$. The second irrigation strip corresponded to $100 \%$ ETc, while the other irrigation depths varied according to the distribution profile of the sprinklers. Rain gauges were installed to measure the water depth applied in each area.

The irrigation system used was the line-source sprinkler system, whose main line consisted of 6" diameter ER aluminum, with spacing of $12.0 \mathrm{~m}$ between sprinklers. The sprinklers used were $8025 \mathrm{HR} 1$ of $1 \frac{1 / 4}{\text { " }} \mathrm{M}$, working at operating pressure of $2.6 \mathrm{Bar}$ and flow rate of $5.72 \mathrm{~m}^{3} \mathrm{~h}^{-1}$. The motor pump set was formed by a $\mathrm{WEG}^{\circ}$ engine coupled to a $\mathrm{KSB}^{\circ}$ pump with flow rate of $150 \mathrm{~m}^{3} \mathrm{~h}^{-1}$. A fixed irrigation interval of 10 days was used, with a total of 24 irrigation events in the plant cane cycle and 26 in the ratoon cane cycle. Irrigation uniformity was determined according to the methodology of Christiansen (1942) and was equal to $82.4 \%$.

Irrigation management was based on crop evapotranspiration (ETc), estimated by reference evapotranspiration $\left(\mathrm{ET}_{0}\right)$ and the crop coefficient (Kc) of Doorenbos \& Kassam (1994). Reference evapotranspiration $\left(\mathrm{ET}_{0}\right)$ was determined daily according to Eq. 1, using for the calculation the data collected from the class A pan of a weather station located $2.0 \mathrm{~km}$ away from the experimental area.

$$
\mathrm{ET}_{0}=\mathrm{EV} \mathrm{Kp}
$$

where:

$\mathrm{ET}_{0}$ - reference evapotranspiration, $\mathrm{mm} \mathrm{d}^{-1}$;

EV - class A pan evaporation, $\mathrm{mm}$; and,

$\mathrm{Kp}$ - pan correction coefficient (0.65) according to Doorenbos \& Kassam (1994). 
At 330 days after planting (DAP) and after cutting (DAC), stalk yield (TCH) was determined in the three central rows of each experimental unit, from which the stalks were harvested and weighed using a dynamometer with a capacity of $1,000 \mathrm{~kg}$, being expressed in $\mathrm{t}$ of stalks ha-1.

Ten stalks were randomly collected in the experimental units and subjected to analysis in the laboratory of Usina Central Olho D'Água S/A, in which the technological variables were determined: POL of the extracted juice, fiber content (\%Fiber), purity (PUR) and content of total recoverable sugar (TRS, $\mathrm{kg} \mathrm{t}^{-1}$ ). The product between TRS, in $\mathrm{t}^{-1}$, and TCH was used to calculate sugar yield $\left(\mathrm{TPH}, \mathrm{t} \mathrm{ha}^{-1}\right)$. Sugarcane fiber content (\%) is calculated based on the correlation between fibrous residue and industrial fiber, according to Eq. 2 (CONSECANA, 2006).

$$
\operatorname{Fiber}(\%)=\frac{(100 \mathrm{DWB})(\mathrm{WWW} \mathrm{b})}{5(100-\mathrm{b})}
$$

where:

DWB - dry weight of bagasse in oven at $105^{\circ} \mathrm{C}$;

WWB - wet weight of bagasse: fibrous residue, resulting from the pressing at $250 \mathrm{kgf} \mathrm{cm}^{-2} \mathrm{~min}^{-1}$ of $500 \mathrm{~g}$ of a defibered and homogenized cane sample; and,

b $\quad-{ }^{\circ}$ Brix of extracted juice.

Purity (PUR) was determined from the percentage of total soluble solids in the extracted juice, Eq. 3, after the determination of pol and ${ }^{\circ} \mathrm{Brix}$ values.

$$
\text { PUR }=\frac{\text { POL } \%_{\text {Juice }}}{{ }^{\circ} \text { Brix }_{\text {Juice }}} 100
$$

Corrected cane POL (POLc) was determined according to Eq. 4.

$$
\mathrm{POL}_{\mathrm{c}}=\mathrm{L}_{\text {corrected }}[(1-0.01) \mathrm{IF}] \mathrm{c}
$$

where:

$\mathrm{L}_{\text {corrected }}$ - POL of the extracted juice, \%;
IF - industrial fiber of sugarcane, \%; and,

c $\quad-0.955$, factor to transform from extracted juice POL to absolute juice POL.

Total recoverable sugars (TRS) were determined based on Eq. 5.

$$
\mathrm{TRS}=(10 \mathrm{~S}-0.76 \mathrm{~F}-6.9)\left(\frac{5}{3}-\frac{200}{3} \mathrm{P}\right)
$$

where:

TRS - total recoverable sugar of cane stalks, $\mathrm{kg} \mathrm{t}^{-1}$;

S - sucrose, \%;

F - fiber, \%; and,

P - purity, \%.

The obtained data were subjected to analysis of variance by test $\mathrm{F}$ at $\mathrm{p} \leq 0.05$. The means of the varieties were subjected to Tukey test at $\mathrm{p} \leq 0.05$, while the irrigation depths and nitrogen doses were subjected to polynomial regression analysis, with the help of the R package programs (R Core Team, 2017).

\section{Results AND Discussion}

The total precipitation for plant cane $(01 / 05 / 2015$ to $12 / 01 / 2015$ - 330 days) was equal to $770 \mathrm{~mm}$ and the effective precipitation to $620 \mathrm{~mm}$, but $58 \%$ of the total precipitation (446.6 $\mathrm{mm}$ ) occurred between the months of May and September 2015, period in which the mean air temperature was around $24.5^{\circ} \mathrm{C}$ (Figure 1). July 2015 was the wettest month, with a total of $175.5 \mathrm{~mm}$.

In the ratoon cane cycle (01/07/2016 to 12/01/2016 - 330 days), the total precipitation was $785.0 \mathrm{~mm}$ and the effective precipitation was $636.7 \mathrm{~mm}$, but $678.0 \mathrm{~mm}$ of the total precipitation (86.4\%) were recorded from January to June 2016 (Figure 1). May 2016 was the wettest month, with $177 \mathrm{~mm}$ and mean temperature of $25.2^{\circ} \mathrm{C}$. Considering the two cycles, $90.6 \%$ of the precipitation occurred, on average, between January and August, characterizing an irregular distribution throughout the year in the municipality of Itambé, Mata Norte region of the State of Pernambuco, Brazil.

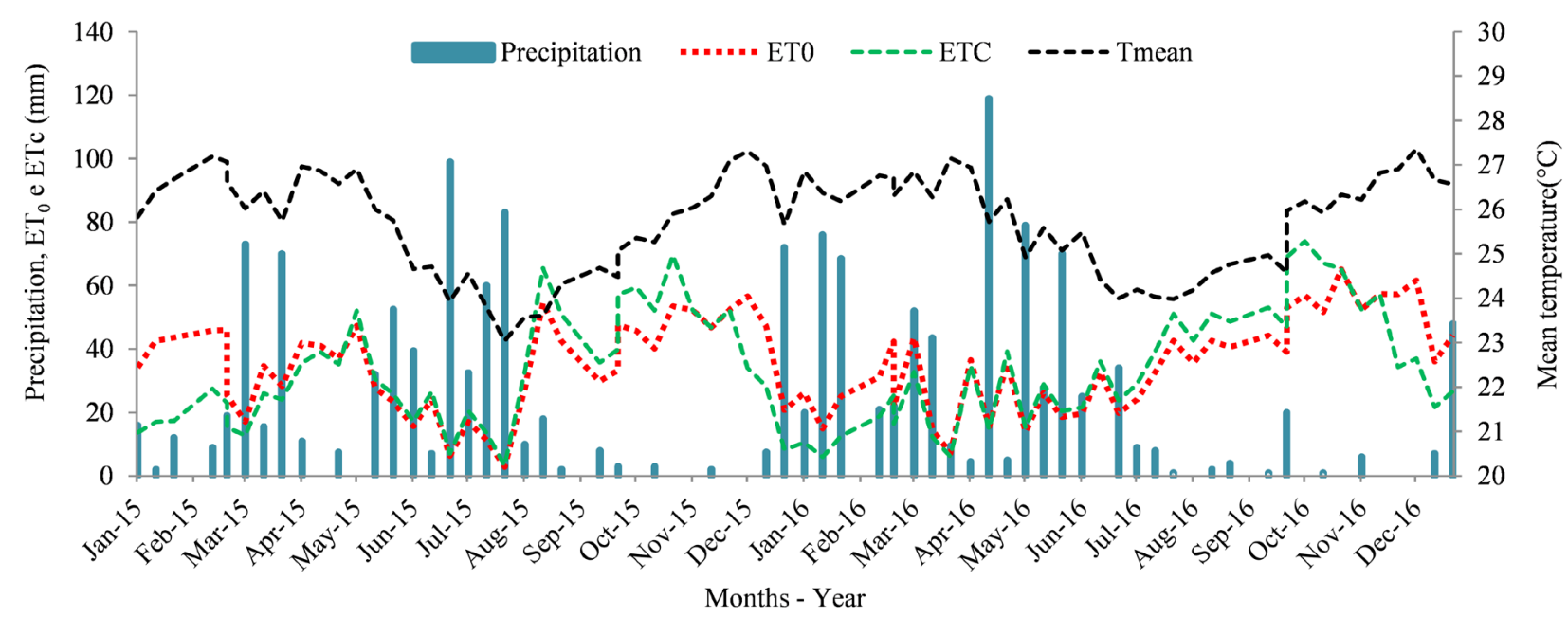

Figure 1. Precipitation, mean temperature (Tmean), reference evapotranspiration $\left(\mathrm{ET}_{0}\right)$ and crop evapotranspiration (ET $\mathrm{c}_{\mathrm{c}}$ for plant cane (PC), year 2015, and ratoon cane (RC), year 2016 
According to Albuquerque et al. (2018), in the Mata Norte region of the State of Pernambuco, Brazil, the normal precipitation is around $1300 \mathrm{~mm}$, and $70 \%$ of this total occurs from March to July. Thus, there is a high probability for water deficit to occur in rainfed crops during the months from August to December.

Reference evapotranspiration $\left(\mathrm{ET}_{0}\right)$ totaled $1,264.9 \mathrm{~mm}$ in the plant cane cycle, with a minimum of $0.28 \mathrm{~mm} \mathrm{~d}^{-1}$ (July 20, 2015), maximum of $5.6 \mathrm{~mm} \mathrm{~d}^{-1}$ (December 10, 2015) and mean of $3.8 \mathrm{~mm} \mathrm{~d}^{-1}$. In the ratoon cane cycle, the accumulated $\mathrm{ET}_{0}$ was $1,238.9 \mathrm{~mm}$, with a minimum of $0.71 \mathrm{~mm} \mathrm{~d}^{-1}$ (March 25, 2016), maximum of $6.51 \mathrm{~mm} \mathrm{~d}^{-1}$ (October 30,2016 ) and mean of $3.71 \mathrm{~mm} \mathrm{~d}^{-1}$ (Figure 1). The highest values of $\mathrm{ET}_{0}$ were observed between August and February and the lowest values between March and July. Therefore, atmospheric demand is lower in the period with higher precipitation due to the decrease in solar radiation, which is attenuated by high cloudiness.

The daily mean of ET for plant cane was $3.2 \mathrm{~mm} \mathrm{~d}^{-1}$ and for ratoon cane was $3.5 \mathrm{~mm} \mathrm{~d}^{-1}$, consistent with the values observed by Meneses \& Resende (2016), which found a mean value of $3.2 \mathrm{~mm} \mathrm{~d}^{-1}$. The similarities observed between both studies may be related to the Kc values considered by Doorenbos \& Kassam (1994).

The summary of the analysis of variance for the yield and technological quality of sugarcane for plant cane (PC) and for ratoon cane (RC) is presented in Table 1. According to the $\mathrm{F}$ test, irrigation depth significantly influenced stalk yield (TCH), total recoverable sugars (TRS), sugar yield (TPH), fiber content and juice purity (PUR\%) at $\mathrm{p} \leq 0.05, \mathrm{p} \leq 0.01$ and $\mathrm{p} \leq 0.0001$.

Silva et al. (2014) report that the increase in irrigation depth favors the increase in sugarcane yield and technological quality. These results are similar to those observed in the present study, although the varieties were different. The variety factor significantly influenced TCH, TRS, TPH and PUR at $\mathrm{p} \leq 0.01$ and $\mathrm{p} \leq 0.05$ by the $\mathrm{F}$ test (Table 1 ).

The total recoverable sugars for plant cane were significantly influenced by the interaction between sugarcane variety and irrigation depth at $\mathrm{p} \leq 0.01$, and PUR of plant cane and PUR of ratoon cane were influenced at $p \leq 0.01$ and $p \leq 0.05$ by the $\mathrm{F}$ test, respectively (Table 1 ). There was single effect of nitrogen doses on the fiber content of the plant cane at $p \leq 0.05$.

The interaction between nitrogen doses and irrigation depth for TCH was significant at $\mathrm{p} \leq 0.00001$ by the $\mathrm{F}$ test in the PC cycle (Table 1). Oliveira et al. (2014) state that nitrogen influences sugarcane yield and technological quality, which can be justified by the amount of nitrogen available to the crop.

Souza et al. (2012) found similar results for these variables when evaluating the agro-industrial performance of sugarcane in the State of Pernambuco, Brazil. The expression of the production components and technological quality of sugarcane depends largely on climatic factors and genetic factors of the studied varieties.

The stalk yield as a function of the irrigation depth in the plant cane cycle (PC) and in the ratoon cane cycle (RC) increased as the applied depth increased, with maximum values of 119.3 and $142.3 \mathrm{t} \mathrm{ha}^{-1}$ at the irrigation depths of $1,324.06$ and 1,242.3 $\mathrm{mm}$, respectively (Figure 2A).

The higher $\mathrm{TCH}$ observed in the cycle of lower irrigation depth (RC) may be associated with the fact that there were more irrigation events, leaving the soil close to field capacity, besides the highest effective precipitation $(636.7 \mathrm{~mm})$, when compared to the PC $(620 \mathrm{~mm})$. Thus, the management of irrigated crop is fundamental for its development and for the increase in its yield (Uribe et al., 2016). This is similar to the results reported by Vieira et al. (2014), who observed an increase in TCH as the applied irrigation depth increased, until reaching a maximum value of $112.3 \mathrm{t} \mathrm{ha}^{-1}$, with $1,537.2 \mathrm{~mm}$.

Farias et al. (2009), when studying the cultivar SP791011 in the northern region of Paraíba, Brazil, in coastal tablelands, reported values of 31.13 and $88.10 \mathrm{t} \mathrm{ha}^{-1}$ for the rainfed treatment and the treatment irrigated with water depth equal to $100 \% \mathrm{ET}_{\mathrm{C}}$, respectively, results that are much lower than those obtained in the present study, which may be associated with the different variety studied.

Morais et al. (2017), in a rainfed study conducted in an area with annual precipitation of $1,753 \mathrm{~mm}$, state that stalk yield tends to be equal or higher in ratoon cane, which is related to

Table 1. Summary of analysis of variance for stalk yield (TCH), total recoverable sugars (TRS), sugar yield (TPH), fiber content (\%) and juice purity (PUR\%) as a function of the irrigation depth, nitrogen doses and sugarcane varieties, for plant cane (PC) and ratoon cane $(\mathrm{RC})$

\begin{tabular}{|c|c|c|c|c|c|c|c|c|c|c|c|}
\hline \multirow{3}{*}{$\begin{array}{l}\text { Sources } \\
\text { of variation }\end{array}$} & \multirow{3}{*}{ GL } & \multicolumn{10}{|c|}{ Test F } \\
\hline & & \multicolumn{2}{|c|}{ TCH (t ha-1) } & \multicolumn{2}{|c|}{ TRS $\left(\mathrm{kg} \mathrm{t}^{-1}\right)$} & \multicolumn{2}{|c|}{ TPH $\left(t h a^{-1}\right)$} & \multicolumn{2}{|c|}{ Fiber (\%) } & \multicolumn{2}{|c|}{ PUR (\%) } \\
\hline & & PC & RC & PC & RC & PC & RC & PC & $\mathbf{R C}$ & PC & RC \\
\hline Blocks & 3 & ns & ns & ns & ns & ns & ns & ns & ns & ns & ns \\
\hline Irrigation depth $(L)$ & 3 & ** & $\star \star \star *$ & ns & $\star \star \star *$ & ** & * & ns & * & ns & $\star \star$ \\
\hline Varieties $(\mathrm{V})$ & 1 & ** & * & ** & ns & ns & * & ns & ns & * & ns \\
\hline$V \times L$ & 3 & ns & ns & ** & ns & ns & ns & ns & ns & ** & * \\
\hline Nitrogen doses (N) & 3 & ns & ns & ns & ns & ns & ns & * & ns & ns & ns \\
\hline$N \times L$ & 9 & 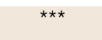 & ns & ns & ns & ns & ns & ns & ns & ns & ns \\
\hline$N \times V$ & 3 & ns & ns & ns & ns & ns & ns & ns & ns & ns & ns \\
\hline$N \times L \times V$ & 9 & ns & ns & ns & ns & ns & ns & ns & ns & ns & ns \\
\hline Residue 1 & 9 & 1254.8 & 976.2 & 105.5 & 25.1 & 20.4 & 0.2 & 0.3 & 13.0 & 11.9 & 77.7 \\
\hline Residue 2 & 12 & 174.0 & 197.6 & 94.5 & 3.3 & 4.5 & 0.1 & 1.4 & 4.0 & 9.4 & 41.6 \\
\hline Residue 3 & 72 & 136.8 & 112.7 & 177.0 & 3.4 & 5.9 & 0.2 & 0.68 & 7.2 & 29.3 & 59.7 \\
\hline Mean overall & - & 100.7 & 121.1 & 143.9 & 146.6 & 14.5 & 11.8 & 12.0 & 84.7 & 11.8 & 84.8 \\
\hline CV $1(\%)$ & - & 35.2 & 25.8 & 7.1 & 28.1 & 31.1 & 4.1 & 4.6 & 4.3 & 4.1 & 6.0 \\
\hline CV $2(\%)$ & - & 13.1 & 1.6 & 6.8 & 10.3 & 14.7 & 3.7 & 10.0 & 2.4 & 3.6 & 4.4 \\
\hline CV $3(\%)$ & - & 11.6 & 8.8 & 9.2 & 10.4 & 16.9 & 4.0 & 6.8 & 3.2 & 6.4 & 5.3 \\
\hline
\end{tabular}

ns, ", "**** - Not significant and significant at $\mathrm{p} \leq 0.05, \mathrm{p} \leq 0.01$ and $\mathrm{p} \leq 0.01$ by $\mathrm{F}$ test 

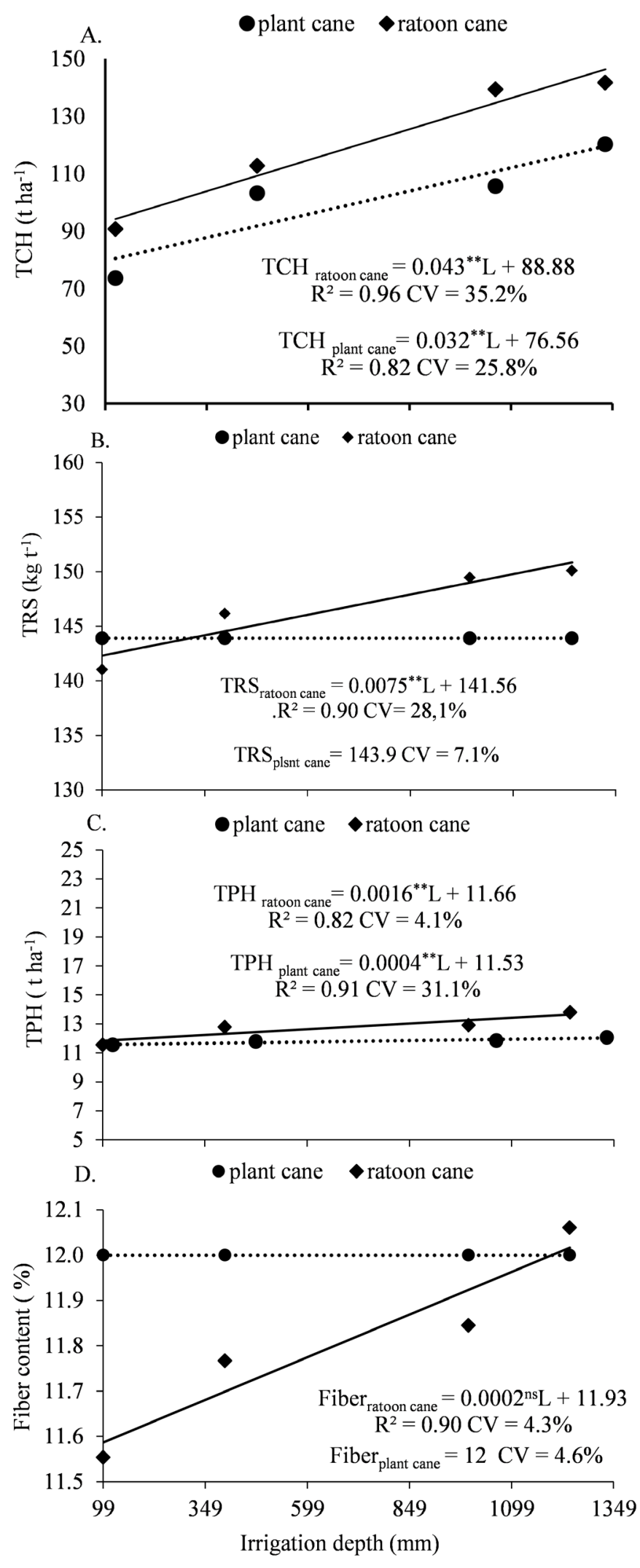

ns, ${ }^{*},{ }^{* *}$ - Not significant and significant at $\mathrm{p} \leq 0.05$ and $\mathrm{p} \leq 0.01$ by $\mathrm{F}$ test, respectively

Figure 2. Stalk yield - TCH (A), total recoverable sugars - TRS (B), sugar yield - TPH (C) and fiber content (D) of plant cane and ratoon cane as a function of irrigation depth $(\mathrm{L})$

the climatic characteristics of each cycle, compared to the plant cane, corroborating the data obtained in the present study. Benett et al. (2011) corroborate these data, since the stalk yield varied from 87 to $99 \mathrm{t} \mathrm{ha}^{-1}$ in the plant cane and from 90 to $104 \mathrm{t} \mathrm{ha}^{-1}$ in the ratoon cane.
The total recoverable sugars for the plant cane were not significantly influenced by the irrigation depth, showing a mean value of $143.9 \mathrm{~kg} \mathrm{t}^{-1}$ (Figure 2B), which is consistent with the data obtained by Silva et al. (2014), who evaluated the production potential of sugarcane under drip irrigation as a function of varieties and cycles and obtained a mean TRS of $140.0 \mathrm{~kg} \mathrm{t}^{-1}$ in the plant cane cycle.

On the other hand, the TRS data in the ratoon cane had a linear fit (Figure 2B), with a maximum yield of $150.8 \mathrm{~kg} \mathrm{t}^{-1}$, obtained at the irrigation depth of $1,242.3 \mathrm{~mm}$. It is also observed that the difference between the lowest and the highest irrigation depths studied was equal to $8.5 \%$, with $\mathrm{R}^{2}$ of $90 \%$ (Figure 2B). Farias et al. (2009) found similar results for TRS production in sugarcane irrigated with $1,407 \mathrm{~mm}$, which produced $147.47 \mathrm{~kg} \mathrm{t}^{-1}$.

Silva et al. (2014) state that the TRS variable is fundamental for the industry and producers, since it is the basis for industrial units to establish the price paid to producers. Considering this aspect, the quality of the stalks resulting from the better TRS is due to the better performance of some varieties when adequately supplied with water throughout the cultivation cycle.

The data of sugar yield (TPH) as a function of the irrigation depth for the plant cane and ratoon cane cycles are found in Figure 2C, which shows a linear fit for both cycles, estimating at 1,324.06 and 1,242.3 $\mathrm{mm}$ the irrigation depth that maximizes TPH, which corresponded to 12.05 and $13.64 \mathrm{tha}^{-1}$, respectively. These results show different responses attributed to the management of the irrigation depth, hence disagreeing with the results reported by Silva et al. (2014), who obtained means higher than those found in this study, because the average sugar yield (TPH) was $20.5 \mathrm{t} \mathrm{ha}^{-1}$ in the first cycle and $21.5 \mathrm{t} \mathrm{ha}^{-1}$ in the second cycle. However, this difference may be linked to the genetic factor of the varieties, since these were different.

The mean fiber content of sugarcane as a function of irrigation depth was $12 \%$ for PC (Figure 2D). The ratoon cane had maximum yield at the irrigation depth of $1,242.3 \mathrm{~mm}$ (12.04\%) and difference between the lowest and highest irrigation depths of $0.45 \%$ (Figure 2D).

According to Prado et al. (2017) and CONSECANA (2006), the ideal amount of fiber varies between 12 and $13 \%$, which does not compromise the available amount of bagasse for burning. The data obtained in this study are within this range considered adequate for fiber in sugarcane, a result similar to that reported by Silva et al. (2014), who obtained a mean values of $12.8 \%$. Farias et al. (2009) obtained a fiber content of $15.07 \%$ for the irrigation depth of $844.4 \mathrm{~mm}$, which is higher than that obtained in this study with a lower irrigation depth.

The stalk yield (TCH) as a function of the studied varieties differed statistically by the Tukey test at $\mathrm{p} \leq 0.05$ for the plant cane and ratoon cane cycles (Figure $3 \mathrm{~A}$ ). For the plant cane cycle, the variety RB002754 had higher stalk yield (105.4 $\left.\mathrm{t} \mathrm{ha}^{-1}\right)$, while RB92579 obtained lower yield (96 t ha-1) (Figure 3A), corroborating the results found by Oliveira et al. (2011), who recorded stalk yield of $97 \mathrm{t} \mathrm{ha}^{-1}$ for the variety RB92579.

Regarding the ratoon cane cycle, the behavior was different from that observed in the plant cane cycle, when the variety 
A.

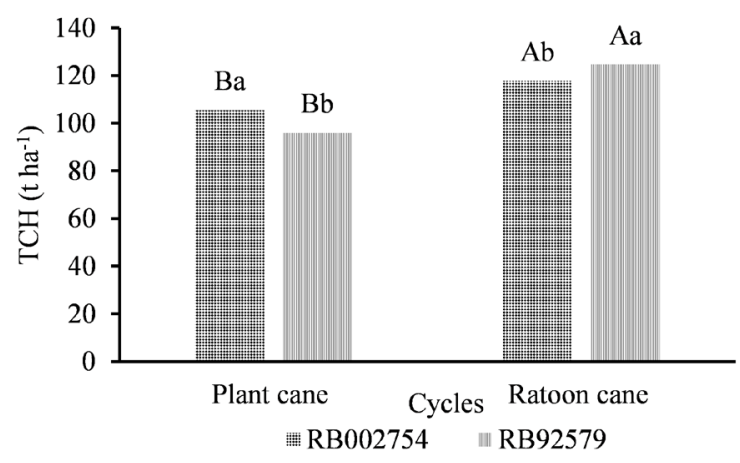

B.

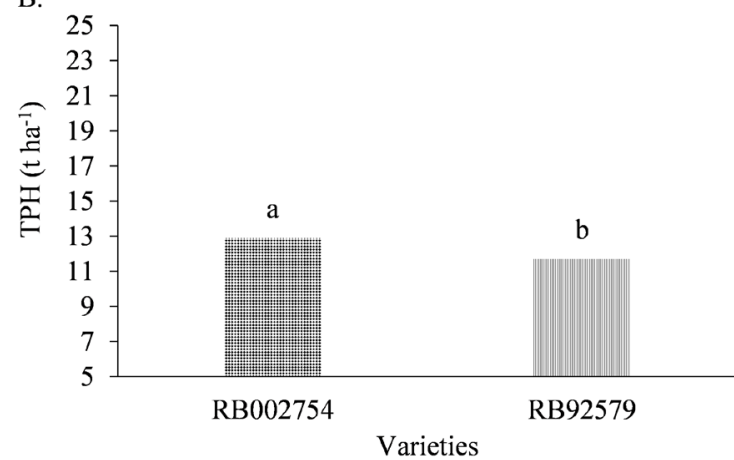

Means followed by the same lowercase letter in each variety and means followed by the same uppercase letter in each cycle do not differ at $\mathrm{p} \leq 0.05$ by Tukey test

Figure 3. Stalk yield (TCH) for plant cane (PC) and ratoon cane (RC) (A), and sugar yield (TPH) for RC (B) as a function of the studied varieties

RB92579 had higher mean of stalk yield (124.6 $\left.\mathrm{t} \mathrm{ha}^{-1}\right)$ compared to RB002754 (117.6 $\mathrm{t} \mathrm{ha}^{-1}$ ) (Figure 3A). It is also important to highlight that there were increments of 12.2 and $28.6 \mathrm{t} \mathrm{ha}^{-1}$ when the varieties RB002754 and RB92579 were compared between the plant cane and the ratoon cane, respectively.

Abreu et al. (2013), when studying sugarcane in the coastal tablelands of Alagoas, observed that the varieties of medium to late maturation, such as RB92579, did not have higher values of height and diameter compared to the other varieties, but they were more productive in terms of stalk $\left(102 \mathrm{t} \mathrm{ha}^{-1}\right)$, similar to what was observed for the ratoon cane cycle in the present study.

Sugar yield (TPH) as a function of the studied varieties differed statistically at $\mathrm{p} \leq 0.05$ by the Tukey test in the ratoon cane cycle (Figure 3B). The variety RB002754 had higher mean of TPH (12.9 tha-1) compared to RB92579 (11.7 $\mathrm{t} \mathrm{ha}^{-1}$ ) (Figure 3B). Abreu et al. (2013) observed, in ratoon cane, lower TPH yields for the variety RB92579, since RB867515 was the one that had the highest values of TCH, a result similar to that of the present study.

The interaction of variety considering each irrigation depth for total recoverable sugars (TRS) of the plant cane cycle is presented in Figure 4A. The data were described by a linear regression model for the variety RB92579, and the highest TRS content was obtained when RB92579 was irrigated with $1,324.06 \mathrm{~mm}$, with a value of $150.14 \mathrm{~kg} \mathrm{t}^{-1}$. These results confirm those obtained by Farias et al. (2009), who recorded maximum TRS when using the irrigation depth of $100 \%$ ETc $(1,026.57 \mathrm{~mm})$.

For the variety RB002754, the model fitted as a function of irrigation depths was quadratic, in which the maximum value
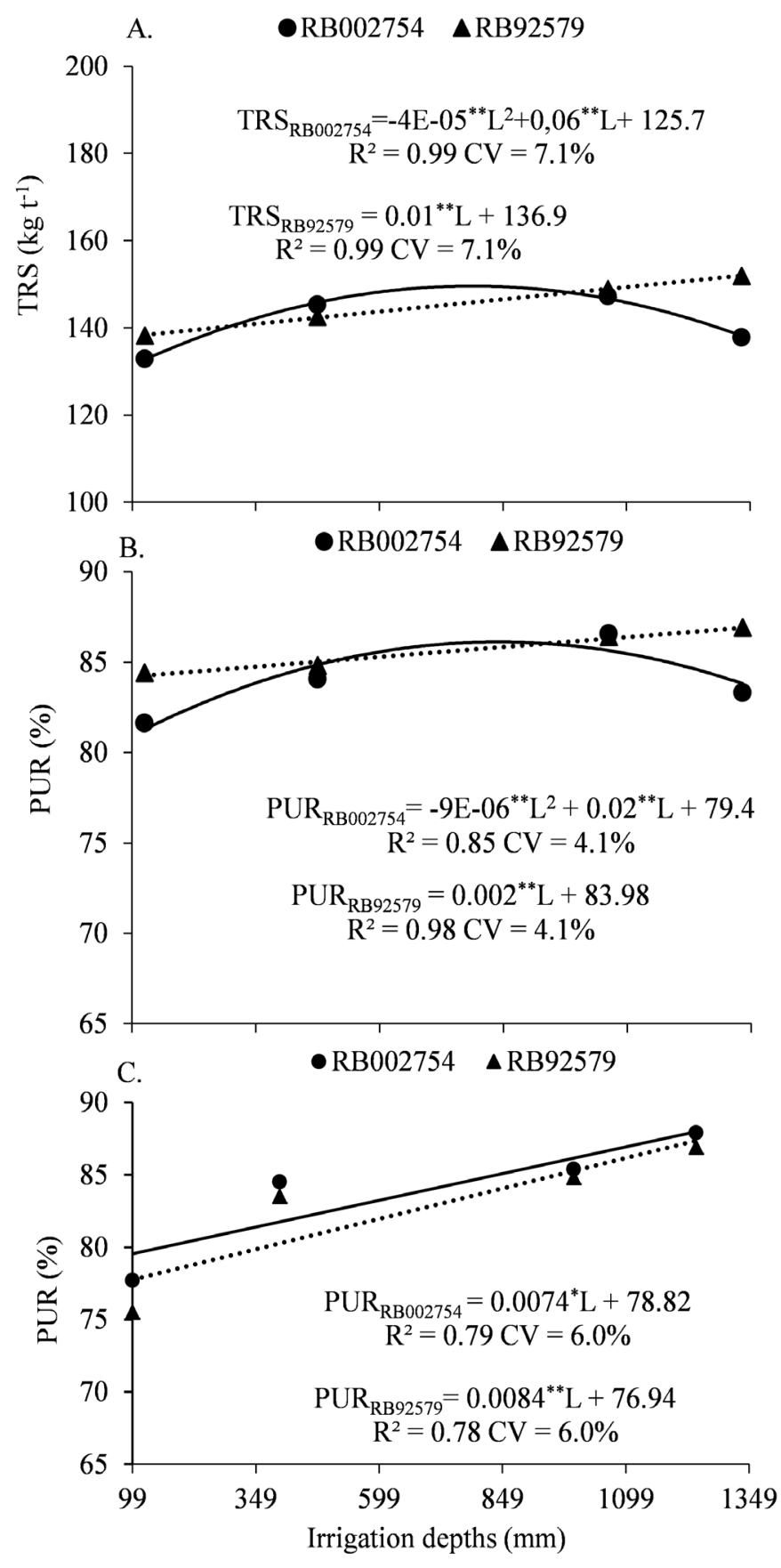

$\mathrm{ns},{ }^{*},{ }^{* *}$ - Not significant and significant at $\mathrm{p} \leq 0.05$ and $\mathrm{p} \leq 0.01$ by $\mathrm{F}$ test, respectively Figure 4. Total recoverable sugars (TRS) for plant cane (A), and juice purity of plant cane $(B)$ and ratoon cane $(C)$ as a function of irrigation depths (L)

(148.6 $\left.\mathrm{kg} \mathrm{t}^{-1}\right)$ was estimated at the irrigation depth of $756.2 \mathrm{~mm}$, which represents a difference of $14.03 \mathrm{~kg} \mathrm{t}^{-1}$, when compared to the sugarcane irrigated with $1,324.06 \mathrm{~mm}$ in the plant cane cycle (Figure 4A).

From this value, it is observed that the contents of recoverable sugars decreased, due to the greater amount of water available for the crop (Figure 4A). This corroborates the statement of Vieira et al. (2012), who obtained at the irrigation depth of $1,617.7 \mathrm{~mm}$ a TRS value of $141.3 \mathrm{~kg} \mathrm{t}^{-1}$. These authors also state that, from this point on, the sucrose content is usually negatively affected by excess water at the maturation stage.

In addition, the variety RB92579 obtained higher TRS yields compared to RB002754 under virtually all irrigation depths, except $473.67 \mathrm{~mm}$ (Figure 4A). These values are similar 
to those found by Campos et al. (2014), who obtained TRS values ranging from 106 to $146 \mathrm{~kg} \mathrm{t}^{-1}$ among the varieties.

For the variety RB002754 considering each irrigation depth for PUR in the plant cane cycle, there was a quadratic adjustment (Figure 4B). It can be noted that at the irrigation depth of $124.06 \mathrm{~mm}$, there was a lower PUR value, increasing as the irrigation depth increased, up to the inflection point of the curve at the irrigation depth of $1111.11 \mathrm{~mm}$ to approximately $90.51 \%$, followed by a reduction with the increase in irrigation depth, with PUR value of $90.10 \%$ for the irrigation depth of $1324.06 \mathrm{~mm}$ (Figure 4B). This is consistent with the results of Carvalho et al. (2009), who observed an increment in PUR with the increase of irrigation depth to an optimal point (290 $\mathrm{mm})$, followed by a reduction.

For the variety RB92579, there was a linear adjustment as a function of irrigation depths (Figure 4B) in the plant cane cycle. Compared to the lowest irrigation depth $(124.06 \mathrm{~mm})$, the PUR increased by $2.7 \%$ with the highest irrigation depth studied (1324.06 mm) (Figure 4B).

Juice purity (PUR) indicates the sucrose content, which is related to the degree of ripening of sugarcane. Thus, the riper the sugarcane, the higher the PUR, as there will be greater accumulation of sucrose because, with the deterioration and aging of sugarcane, purity tends to decrease, causing a change in sugar color. The ideal is to obtain purity higher than $80 \%$ (CONSECANA, 2006; Campos et al., 2014; Silva et al., 2014).

In the ratoon cane cycle, there was a significant effect of the interaction between variety and irrigation depth for juice purity (Figure 4C). Both RB002754 and RB92579 showed the same behavior, with a positive increase as the irrigation depth increased, with the maximum yield obtained at irrigation depth of $1242.3 \mathrm{~mm}$, with PUR values of 88.0 and $87.3 \%$, respectively.

These values are within the standards established by CONSECANA (2006), which reports that industrial units can only refuse to receive cargoes of sugarcane if they are below $75 \%$ purity.

The fiber content of the plant cane (PC) as a function of nitrogen doses had a linear adjustment (Figure 5A). As the $\mathrm{N}$ dose increased, there was a reduction in fiber content, with a difference of $5 \%$ between the lowest dose $\left(0 \mathrm{~kg} \mathrm{ha}^{-1} \mathrm{~N}\right)$ and the highest dose $\left(200 \mathrm{~kg} \mathrm{ha}^{-1} \mathrm{~N}\right)$.

Prado et al. (2017) state that the fiber content is of great importance in the sugarcane industry in relation to the agricultural aspect; thus, the fiber-rich varieties have greater resistance to lodging and pests. Oliveira et al. (2012) report that fiber content below $10.5 \%$ is undesirable because of the energy balance in the mills, since it is necessary to burn more bagasse to maintain the calorific power in the boilers.

Nitrogen doses and irrigation depths for stalk yield (TCH) caused a quadratic fit with interaction (Figure $5 \mathrm{~B}$ ). The maximum estimated $\mathrm{TCH}$ was $120.7 \mathrm{t} \mathrm{ha}^{-1}$ at the $\mathrm{N}$ dose of $127 \mathrm{~kg} \mathrm{ha}^{-1}$ and irrigation depth of $1266.6 \mathrm{~mm}$. By comparing the $\mathrm{N}$ dose of $0 \mathrm{~kg} \mathrm{ha}^{-1}$ combined with the irrigation depth of $124.06 \mathrm{~mm}$, with the points of maximum yield, it was possible to observe an increase of $51.50 \mathrm{t} \mathrm{ha}^{-1}$ in stalk yield per hectare.

Vieira-Megda et al. (2015) report that nitrogen fertilization at increasing doses up to $175 \mathrm{~kg} \mathrm{ha}^{-1}$ associated with irrigation depths results in increase of stalk yield. Andrade Junior et al.

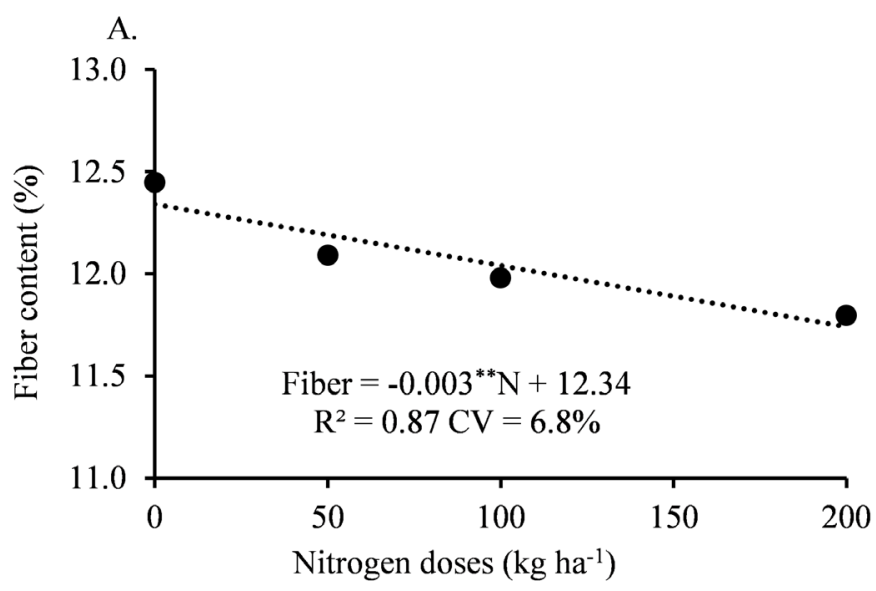

$\mathrm{TCH}=59.572+0.2032 * \mathrm{~N}+0.0798 * \mathrm{~L}-0.0008 * \mathrm{~N}^{2}-0.0000157 * \mathrm{~N} * \mathrm{~L}-0.0000315 * \mathrm{~L}^{2}$ $\mathrm{R}^{2}=0.75 \mathrm{CV}=14.3 \%$

B.

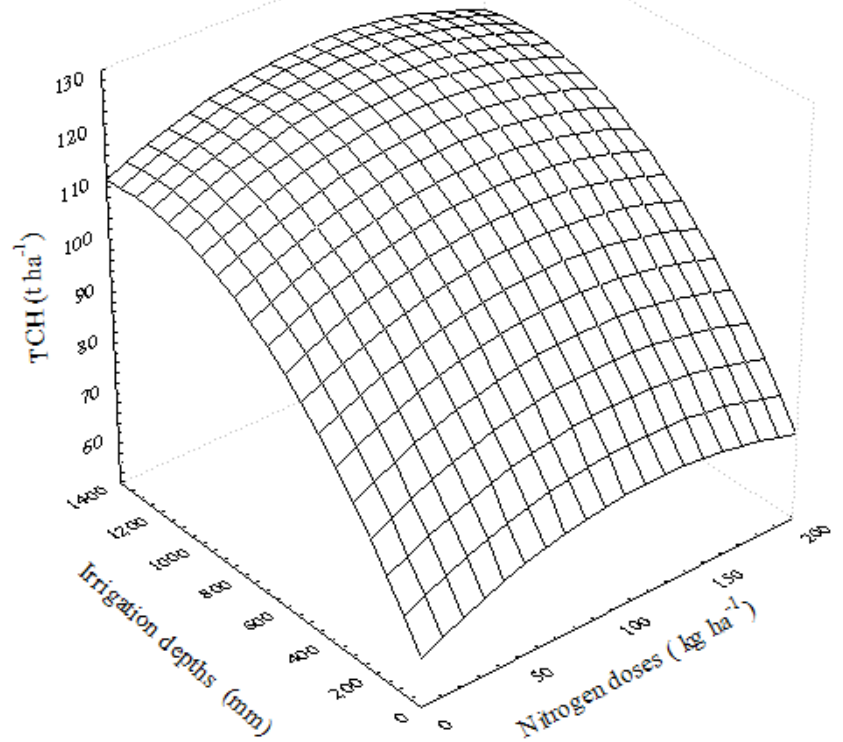

ns, ${ }^{*},{ }^{* *}$ - Not significant and significant at $\mathrm{p} \leq 0.05$ and $\mathrm{p} \leq 0.01$ by $\mathrm{F}$ test, respectively Figure 5. Fiber content as a function of nitrogen doses $(\mathrm{A})$ and stalk yield (TCH) of plant cane (B) as a function of irrigation depths (L) and nitrogen doses $(\mathrm{N})$

(2012) state that sugarcane when fertilized with nitrogen has $49 \%$ higher yield than that produced without fertilization, with a positive increment as the nitrogen dose is increased, results that are consistent with those obtained in the present study.

\section{Conchusions}

1. Sugarcane irrigated with the highest depths of $1,324.06$ and $1,242.3 \mathrm{~mm}$ in plant cane and ratoon cane respectively produced 38.40 and $49.14 \mathrm{t}_{\text {stalks ha }}{ }^{-1}$ and 0.48 and $1.82 \mathrm{t} \mathrm{sugar} \mathrm{ha}^{-1}$ more compared to plants irrigated with the lowest depths of 124.06 and $99.4 \mathrm{~mm}$.

2 . The highest stalk yield was obtained with the combination of $120.7 \mathrm{~kg} \mathrm{ha}^{-1}$ of $\mathrm{N}$ and $1266.6 \mathrm{~mm}$ of irrigation depth.

3. Sugarcane technological quality is positively correlated with the increase of the irrigation depth in the plant cane and ratoon cane cycles and negatively correlated with nitrogen. 


\section{Literature Cited}

Abreu, M. L.; Silva, M. A.; Teodoro, I.; Holanda, L. A.; Sampaio Neto, G. D. Crescimento e produtividade de cana-de-açúcar em função da disponibilidade hídrica dos Tabuleiros Costeiros de Alagoas. Bragantia, v.72, p.262-270, 2013. https://doi.org/10.1590/ brag. 2013.028

Albuquerque, F. S.; Silva, E. F. F.; Lopes, P. M. O.; Moura, G. B. A.; da Silva, A. O. Condições hídricas e crescimento vegetal de cana- de -açúcar no semiárido brasileiro. Revista Ceres. v.65, p.111-119, 2018. https://doi.org/10.1590/0034-737x201865020001

Andrade Júnior, A. S.; Bastos, E. A.; Ribeiro, V. Q.; Duarte, J. A. L.; Braga, D. L.; Noleto, D. H. Níveis de água, nitrogênio e potássio por gotejamento subsuperficial em cana-de- açúcar. Pesquisa Agropecuária Brasileira, v.47, p.76-84, 2012. https://doi. org/10.1590/S0100-204X2012000100011

Benett, C. G. S.; Buzetti, S.; Silva, K. S.; Teixeira Filho, M. C. M.; Maestrelo, P. R. Produtividade e desenvolvimento da canaplanta e soca em função de doses e fontes de manganês. Revista Brasileira de Ciência do Solo, v. 35, p.1661-1667, 2011. https:// doi.org/10.1590/S0100-06832011000500020

Campos, P. F.; Alves Júnior, J.; Casaroli, D.; Fontoura, P. R.; Evangelista, A. W. P. Variedades de cana-de-açúcar submetidas à irrigação suplementar no cerrado goiano. Engenharia Agrícola, v.34, p.11391149, 2014. https://doi.org/10.1590/S0100-69162014000600010

Carvalho, C. M. de; Azevedo, H. M. de; Dantas Neto J.; Farias, C. H. de A.; Silva, C. T. S. da.; Gomes Filho R. R. Rendimento de açúcar e álcool da cana-de-açúcar submetida a diferentes níveis de irrigação. Revista Brasileira de Ciência Agrárias, v.4, p.72-77, 2009. https://doi.org/10.5039/agraria.v4ila12

Christiansen, J.E. Irrigation by sprinkling. Berkley: University of California, 1942. 124p.

CONSECANA - Conselho de Produtores de Cana-de -Açúcar, Açúcar e Etanol do Estado de São Paulo. Manual de instruções. 5.ed. Piracicaba: CONSECANA, 2006. 112p.

Dellabiglia, W. J.; Gava, G. J. C.; Arlanch, A. B.; Villas Boas, R. L.; Cantarella, H.; Rossetto, R. Produtividade de cana-deaçúcar fertirrigada com doses de $\mathrm{N}$ e inoculadas com bactérias diazotróficas. Irriga, v.1, p.29-34, 2018. https://doi.org/10.15809/ irriga.2018v1n1p28-41

Donagema, G. K.; Campos, D. V. B. de; Calderano, S. B.; Teixeira, W. G.; Viana, J. H. M. Manual de métodos de análise de solo. 2.ed. Rio de Janeiro: Embrapa Solos, 2011. 230p.

Doorenbos, J.; Kassam, A.H. Efeito da água no rendimento das culturas. Campina Grande: UFPB, 1994. 306p. Estudos FAO: Irrigação e Drenagem, 33

Farias C. H. A.; Fernandes, P. D.; Gheyi, H. R.; Dantas Neto, J. Qualidade industrial de cana-de-açúcar sob irrigação e adubação com zinco, em Tabuleiro Costeiro paraibano. Revista Brasileira de Engenharia Agrícola e Ambiental, v.13, p.419-428, 2009. https:// doi.org/10.1590/S1415-43662009000400008

Meneses, T. N.; Resende, R. S. Influência de épocas de plantio na eficiência do uso da água da chuva em cultivo irrigado de canade-açúcar. Irriga, v.1, p.291-305, 2016. https://doi.org/10.15809/ irriga.2016vln1p291-305

Morais, K. P.; Medeiros, S. L. P.; Silva, S. D. A.; Boelter, J. H.; Dias, F. S. Produtividade de colmos em clones de cana-de-açúcar. Revista Ceres, v.64, p.291-297, 2017. https://doi.org/10.1590/0034$737 \times 201764030010$
Oliveira, E. C. A.; Freire, F. J.; Oliveira, A. C.; Simões Neto, D. E.; Rocha, A. T. da; Carvalho, L. A. Produtividade, eficiência de uso da água e qualidade tecnológica de cana-de-açúcar submetida a diferentes regimes hídricos. Pesquisa Agropecuária Brasileira, v.46, p.617-625, 2011. https://doi.org/10.1590/S0100204X2011000600007

Oliveira, F. M. O.; Aguilar, P. B.; Teixeira, M. F. F.; Aspiazú, I.; Monção, F. P.; Antunes, A. P. S. Características agrotecnólogicas de canade-açúcar em diferentes épocas de supressão de irrigação e níveis de adubação. Semina: Ciências Agrárias, v.35, p.1587-1606, 2014. https://doi.org/10.5433/1679-0359.2014v35n3p1587

Oliveira, M. F.; Aspiazú, I.; Kondo, M. K.; Borges, I. D.; Pegoraro, R. F.; Vianna, E. J. Avaliação tecnológica de variedades de canade-açúcar influenciadas por diferentes adubações e supressões de irrigação. Revista Ceres, v.59, p.832-840, 2012. https://doi. org/10.1590/S0034-737X2012000600014

Prado, E. A. F.; Vitorino, A. C. T.; Mauad, M.; Ensinas, S. C.; Paim, L. R. Características tecnológicas da cana-de-açúcar sob aplicação de doses de vinhaça em Latossolo Vermelho distroférrico. Revista de Ciências Agroveterinárias, v.16, p.386-395, 2017. https://doi. org/10.5965/10.5965/223811711642017386

R Core Team. R: A language and environment for statistical computing. Vienna: R Foundation for Statistical Computing, 2017. Available on: <URL:http://www.rproject.org/>. Accessed on: Nov. 2018.

Silva, M. A.; Arantes, M. T.; Rhein, A. F. L.; Gava, G. J. C.; Kolln, O. T. Potencial produtivo da cana-de-açúcar sob irrigação por gotejamento em função de variedades e ciclos. Revista Brasileira de Engenharia Agrícola e Ambiental, v.18, p.241-249, 2014. https://doi.org/10.1590/S1415-43662014000300001

Simões Neto, D. E.; Oliveira, A. C. de; Freire, F. J.; Freire, M. B. G. dos S.; Nascimento, C. W. A. do; Rocha, A. T. da. Extração de fósforo em solos cultivados com cana-de-açúcar e suas relações com a capacidade tampão. Revista Brasileira de Engenharia Agrícola e Ambiental, v.13, p.840-848, 2009. https://doi.org/10.1590/S141543662009000700005

Souza, P. H. N.; Bastos, G. B.; Anunciação Filho, C. J.; Dutra Filho, J. A.; Machado, P. R. Avaliação de genótipos de cana-de-açúcar para início de safra na Microrregião Centro de Pernambuco. Revista Ceres, v.59, p.677-683, 2012. https://doi.org/10.1590/ S0034-737X2012000500013

Uribe, R. A. M.; Gava, G. J. C.; Kolln, O. T.; Saad, J. C. C. Estimativa do acúmulo de fitomassa da soqueira de cana-de-açúcar fertirrigada com doses de $\mathrm{N}$-fertilizante utilizando modelo de simulação. Irriga, v.1 edição especial, p.126-139, 2016. https:// doi.org/10.15809/irriga.2016v1n1p126-139

Vieira, G. H. S.; Mantovani, E. C.; Sediyama, G. C.; Costa, E. L.; Delazari, F. T. Produtividade de colmos e rendimento de açúcares da cana-de-açúcar em função de lâminas de água. Irriga, v.17, p.234-244, 2012. https://doi.org/10.15809/irriga.2012v17n2p234

Vieira, G. H. S.; Mantovani, E. C.; Sediyama, G. C.; Delazari, F. T. Indicadores morfo-fisiológicos do estresse hídrico para a cultura da cana-de-açúcar em função de lâminas de irrigação. Bioscience Journal, v.30, p.65-75, 2014.

Vieira-Megda, M. X.; Mariano, E.; Leite, J. M.; Franco, H. C. J.; Vitti, A. C.; Megda, M. M. Contribution of fertilizer nitrogen to the total nitrogen extracted by sugarcane under Brazilian field conditions. Nutrient Cycling in Agroecosystems, v.101, p.241-257, 2015. https://doi.org/10.1007/s10705-015-9676-7 